\title{
Total quality management: a brief review
}

\author{
Mehrsa Bakhtiyari ${ }^{1}$ \\ ${ }^{1}$ Affiliation not available
}

April 28, 2020

Mehrsa Bakhtiyari ${ }^{1^{*}}$

1 Department of Management, Tehran Markaz Azad University, Tehran, Iran.

* Correspondence: mehrsa.bakhtiari@yahoo.com

\section{Abstract}

Total quality management (TQM) is a customer-oriented process which aims for continuous improvement of business operations. In this study, the principles, merits and strategies of TQM are briefly discussed.

\section{Introduction}

Total quality management (TQM) refers to a management method aimed at long-term success through customer satisfaction. In TQM, every member of an organization is involved in improving processes, products, services, and the culture in which they work. TQM ensures that organizations attain a high degree of differentiation in order to reduce costs.

A successful TQM involves three different areas: contributions from quality leaders, formal evaluation models and empirical research. Deming $(1982,1986)$ studies the use of statistical methods for quality control, and proposed 14 principles to improve quality in organizations, based on the following ideas: leadership, an improvement philosophy, the right production from the beginning, training for managers and employees, internal communication aimed at the elimination of obstacles for cooperation and the suppression of quantitative objectives.

Juran (1986) highlighted the importance of both technical and managerial aspects, and identified the three basic functions of the quality management process: planning, organization and control, as the stages for quality improvement. It was further stated that the aim of management is to reduce the cost of mistakes, reaching a point where the total costs of quality are minimal (Juran and Gryna, 1993).

Ishikawa $(1976,1985)$ noted the significance of training, the usage of cause-effect diagrams for problem solving, and quality circles as a way to achieve continuous improvement. Crosby (1979) proposed 14 steps for quality improvement which include top and intermediate management commitment, quality measurement, evaluation of quality costs, corrective action, training, a zero-defect philosophy, objective setting and employee recognition.

Feigenbaum (1991) analyzed total quality, based solely on leadership and an understanding of the aspects of quality improvement, a commitment to incorporate quality in the firm's practices, and the participation of the entire workforce, the objective being the reduction of total quality costs.

There exist standardized quality models used by organizations in practice as a guide for their implementation of TQM, or in order to carry out self-evaluations of their quality practices. The main models are the Malcolm Baldrige National Quality Award model in the USA, the European Foundation for Quality Management (EFQM) model in Europe and the Deming Application Prize model in Japan. 


\section{Principles of TQM}

There are 8 principles of TQM, which are summarized below as follows:

1. Customer-focused: The customer ultimately determines the level of quality. No matter what an organization does to ensure quality improvement - training employees, integrating quality into the design process, or upgrading computers or software - the customer determines whether the efforts were worthwhile.

2. Total employee involvement: All employees participate in working toward common goals. Total employee commitment can only be obtained after fear has been driven from the workplace, when empowerment has occurred, and when management has provided the proper environment. High-performance work systems integrate continuous improvement efforts with normal business operations. Self-managed work teams are one form of empowerment.

3. Process-centered: A fundamental part of TQM is a focus on process thinking. A process is a series of steps that take inputs from suppliers (internal or external) and transforms them into outputs that are delivered to customers (internal or external). The steps required to carry out the process are defined, and performance measures are continuously monitored in order to detect unexpected variation.

4. Integrated system: Although an organization may consist of many different functional specialties often organized into vertically structured departments, it is the horizontal processes interconnecting these functions that are the focus of TQM.

5. Micro-processes add up to larger processes, and all processes aggregate into the business processes required for defining and implementing strategy. Everyone must understand the vision, mission, and guiding principles as well as the quality policies, objectives, and critical processes of the organization. Business performance must be monitored and communicated continuously.

6. An integrated business system may be modeled after the Baldrige Award criteria and/or incorporate the ISO 9000 standards. Every organization has a unique work culture, and it is virtually impossible to achieve excellence in its products and services unless a good quality culture has been fostered. Thus, an integrated system connects business improvement elements in an attempt to continually improve and exceed the expectations of customers, employees, and other stakeholders.

7. Strategic and systematic approach: A critical part of the management of quality is the strategic and systematic approach to achieving an organization's vision, mission, and goals. This process, called strategic planning or strategic management, includes the formulation of a strategic plan that integrates quality as a core component.

8. Continual improvement: A large aspect of TQM is continual process improvement. Continual improvement drives an organization to be both analytical and creative in finding ways to become more competitive and more effective at meeting stakeholder expectations.

9. Fact-based decision making: In order to know how well an organization is performing, data on performance measures are necessary. TQM requires that an organization continually collect and analyze data in order to improve decision making accuracy, achieve consensus, and allow prediction based on past history.

10. Communication: During times of organizational change, as well as part of day-to-day operation, effective communication plays a large part in maintaining morale and in motivating employees at all levels. Communications involve strategies, method, and timeliness.

\section{Gains of TQM}

TQM serves several merits as follows:

- Strengthened competitive position

- Adaptability to changing or emerging market conditions and to environmental and other government regulations

- Higher productivity 
- Enhanced market image

- Elimination of defects and waste

- Reduced costs and better cost management

- Higher profitability

- Improved customer focus and satisfaction

- Increased customer loyalty and retention

- Increased job security

- Improved employee morale

- Enhanced shareholder and stakeholder value

- Improved and innovative processes

\section{Strategies for implementing TQM}

In order to reap the benefits of TQM, several strategies have been proposed as summarized below:

\section{Strategy 1: The TQM element approach}

The TQM element approach takes key business processes and/or organizational units and uses the tools of TQM to foster improvements. This method was widely used in the early 1980s as companies tried to implement parts of TQM as they learned them. Examples of this approach include quality circles, statistical process control, Taguchi methods, and quality function deployment.

\section{Strategy 2: The guru approach}

The guru approach uses the teachings and writings of one or more of the leading quality thinkers as a guide against which to determine where the organization has deficiencies. The organization makes appropriate changes to remedy those deficiencies.

\section{Strategy 3: The organization model approach}

In this approach, individuals or teams visit organizations that have taken a leadership role in TQM and determine their processes and reasons for success. They then integrate these ideas with their own ideas to develop an organizational model adapted for their specific organization.

\section{Strategy 4: The Japanese total quality approach}

Organizations using the Japanese total quality approach examine the detailed implementation techniques and strategies employed by Deming Prize-winning companies and use this experience to develop a long-range master plan for in-house use.

\section{Strategy 5: The award criteria approach}

When using this model, an organization uses the criteria of a quality award (e.g., the Deming Prize, the European Quality Award, or the Malcolm Baldrige National Quality Award), to identify areas for improvement. Under this approach, TQM implementation focuses on meeting specific award criteria. Although some argue that this is not an appropriate use of award criteria, some organizations do use this approach and it can result in improvement.

\section{Conclusion}

This study has given a brief review of TQM, its principles, benefits as well as strategies that managers should consider for its successfull implementation in their organization. If well implemented, the long-term success as well as customer satisfaction, which are major aims of any organization, will be met and could even be surpassed.

\section{References}

Crosby, P.B. (1979), Quality is Free: The Art of Making Quality Certain, Hodder \& Stoughton, New York, NY. 
Deming, W.E. (1982), Quality, Productivity and Competitive Position, MIT Center for Advanced Engineering, Cambridge, MA.

Deming, W.E. (1986), Out of the Crisis, MIT Center for Advanced Engineering, Cambridge, MA.

Feigenbaum, A.V. (1991), Total Quality Control, McGraw-Hill, New York, NY.

Ishikawa, K. (1976), Guide to Quality Control, Asian Productivity Organization, Tokyo.

Ishikawa, K. (1985), What Is Total Quality Control? The Japanese Way, Prentice Hall, London.

Juran, J.M. (1986), "Quality trilogy", Quality Progress, August, pp. 14-24. Juran, J.M. and Gryna, F.M. (1993), Quality Planning and Analysis: From Product Development Through Use, McGraw-Hill, New York, NY. 